\title{
Natural self-interest, interactive representation, and the emergence of objects and Umwelt: An outline of basic semiotic concepts for biosemiotics
}

\author{
Tommi Vehkavaara \\ Department of Mathematics, Statistics, and Philosophy, University of Tampere, \\ 33014 University of Tampere, Finland \\ e-mail: tommi.vehkavaara@uta.fi
}

\begin{abstract}
In biosemiotics, life and living phenomena are described by means of originally anthropomorphic semiotic concepts. This can be justified if we can show that living systems as self-maintaining far from equilibrium systems create and update some kind of representation about the conditions of their self-maintenance. The point of view is the one of semiotic realism where signs and representations are considered as real and objective natural phenomena without any reference to the specifically human interpreter. It is argued that the most basic concept of representation must be forward looking and that both C. Peirce's and J. v. Uexküll's concepts of sign assume an unnecessarily complex semiotic agent. The simplest representative systems do not have phenomenal objects or Umwelten at all. Instead, the minimal concept of representation and the source of normativity that is needed in its interpretation can be based on M. Bickhard's interactivism. The initial normativity or natural self-interest is based on the 'utility-concept' of function: anything that contributes to the maintenance of a far from equilibrium system is functional to that system - every self-maintaining far from equilibrium system has a minimal natural self-interest to serve that function, it is its existential precondition. Minimal interactive representation emerges when such systems become able to switch appropriately between two or more means of maintaining themselves. At the level of such representations, a potentiality to detect an error may develop although no objects of representation for the system are provided. Phenomenal objects emerge in systems that are more complex. If a system creates a set of ongoingly updated 'situation images' and can detect temporal invariances in the updating process, these invariances constitute objects for the system itself. Within them, a representative system gets an Umwelt and becomes capable of experiencing triadic signs. The relation between representation and its object is either iconic or indexical at this level. Correspondingly as in Peirce's semeiotic, symbolic signs appear as more developed - for the symbolic signs, a more complex system is needed.
\end{abstract}




\section{Why biosemiotics?}

Modern biosemiotics, as a discipline or a united field of discourse, can be said to born about the decade ago, at the turn of the 1990s. At that time, isolated biosemiotically oriented researchers (and small discussion groups) found a connection with each other, and the name 'biosemiotics' was taken into common use. ${ }^{1}$ As an approach to the phenomenon of life, modern biosemiotics has been characterized following ways:

The sign rather than the molecule is the basic unit for studying life. (Hoffmeyer 1995: 369.)

Biosemiotics can be defined as the science of signs in living systems. A principal and distinctive characteristic of semiotic biology lays in the understanding that in living, entities do not interact like mechanical bodies, but rather as messages, the pieces of text. (Kull 1999a: 386.)

According to biosemiotics all processes going on in animate nature at whatever level, from the single cell to the ecosystem, should be analysed and conceptualised in terms of their character of being sign-processes. This does not imply any denial of the anchoring of such processes in well-established physical and chemical lawfulness. Only, it is claimed that life-processes are part of and are organised in obedience to a semiotic dynamic. Biosemiotics, then, is concerned with the sign-aspects of the processes of life itself (not with the sign-character of the theoretical structure of life-sciences). (Hoffmeyer 1998: 82.)

Biosemiotics - $[\ldots]$ biology that interprets living systems as sign systems. (Emmeche, Kull, Stjernfelt 2002: 26).

Question: Why should we approach life by mixing our internally meaningful semiotic concepts to the externally describable natural phenomenon of life? What makes the phenomenon of life so peculiar that we should develop bio-semiotics?

Answer: Firstly, living systems are not just complex collections of atoms and molecules, but they are far from equilibrium systems. They are relatively constant forms - like flames and vortices in the continuous flow of matter. If this continuous change ceases,

\footnotetext{
1 Although modern biosemiotics has had a number of antecedents since the times of Peirce, it was not until the 1990s, when Thomas Sebeok, Jesper Hoffmeyer, Claus Emmeche, Thure von Uexküll, and Kalevi Kull (among others) begun to organize seminars, publications, etc. where the biosemiotics was the leading theme. (About the history of biosemiotics, see Kull 1999a, b, and Hoffmeyer 2002.)
} 
the system will start to fall apart and loose its identity as a living system.

Secondly, despite the ethereal vulnerability of far from equilibrium systems, especially living systems have a tendency to stay alive - although they are mortal, they are also potentially immortal. $^{2}$ We can easily imagine the self-extinction of human race, but the self-extinction of all life seems much more improbable at least, it is most probably far beyond human powers.

Question: What gives the potential immortality to living systems?

Answer: The potential immortality of living systems is due to their readiness to change their behaviour and structure appropriately i.e. directionally - in the pressure of the environmental changes. The minimal criterion for this appropriateness is ultimately the mere survival of the system.

Question: How is this possible? What makes this readiness to appropriate self-reconstruction possible?

Answer: Firstly, the readiness to self-reconstruction requires that living systems are more or less flexible, and secondly, the directionality or appropriateness of this self-reconstruction requires some kind of anticipation of possible future changes in relation with the flexibility of a system. The system has to make some kind of vicariate comparison between anticipated external change and anticipated internal changability and have means to indicate the appropriate action that this vicariate comparison suggests.

Question: What is the general mechanism or functional structure of that anticipation?

Hypothesis: Living systems have to be able to create and update some kind of representation about the external and internal conditions of their self-maintenance. These embodied 'representations' are used as an internal model of the world according to

2 If one looks at the proof, bacteria are still with us and thus constitute a living evidence of the potential immortality of living systems. Moreover, what we and all the current forms of life ultimately are but swarms of (the swarms of) developed and co-operative bacteria (cf. Hoffmeyer 1997c). Although (most) organisms are certainly mortal, it is not the death of an organism but the extinction of its lineage that means the total failure of its self-maintenance. Thus, it is a lineage rather than an organism that fits better the concept of living system (that can be 'potentially immortal'). And if organisms were still considered as living systems, they can be said to have 'life after death' in the form of their descendants. The identity of a system has to be based on continuity rather than on invariable essential characters or structures. 
which the behaviour of a system - especially the use of the constructive power of a system (including the self-constructive power) - is appropriately guided.

If this hypothesis is redeemable, living systems are not describable as merely physical systems, but besides this, they have to be considered - in a certain strict and abstract sense - as real mental systems. ${ }^{3}$ The core idea of biosemiotics follows: "Signs and life are coextensive" (e.g., Stjernfelt 2002: 337).

\section{What biosemiotics could mean?}

If the idea of living systems being mental is based merely on analogy, this will not lead us to anything definitive, because the analogy with the common sense conceptions of mind is at its best only partial, distant, or loose. The more definitive sense to "the core idea of biosemiotics' is needed.

As demonstrated in the line of thought above, they are especially the signs or representations that are usually counted as mental and that therefore attach a mental character to life. Thus to make specifically biosemiotics means a study and search of signs, mind, and other semiotic concepts as they appear in living natural phenomena. Moreover, they have to be taken as (and not mere as if) natural phenomena. Thus, we (should) find ourselves at some kind of semiotic naturalism which, in turn, should lead us to the question what the correct semiotic concepts are and how they should be (re)defined. As I have proposed elsewhere (Vehkavaara 2002: 295-297), the core project in the semiotic naturalism should be a certain kind of naturalization of

3 This is the basic hypothesis - not only of biosemiotics - but of evolutionary epistemology too (Campbell 1974; Lorenz 1973). In evolutionary epistemology, evolutionary adaptation through natural selection is considered as evolutionary learning, i.e. as knowledge gathering. The basic point is to naturalize and generalize the 'intuitive' concept of knowledge - 'true well-justified belief' is a special case of valid and reliable representation. However, the criteria for validity and reliability are hard to distinguish when the subject matter is 'phylogenetic knowledge' etc. (in Vehkavaara 1998, I did not yet fully recognize this). Therefore, the concept of knowledge in evolutionary epistemology is rather the concept of valid representation. It can be noticed that they are exactly the concepts of representation (or sign) and its validity both of which constitute the object of study of Peircean semeiotic, and consequently, of its extension (or application) to biosemiotics. 
semiotic concepts. They should be based solely on the objects of external experience. ${ }^{4}$ The main reason for this project is the hope that within it, the risk of falling into anthropomorphic error, or more generally into 'zoomorphic' error, would decrease. It is too easy to make the erroneous generalization of cognitive structures peculiar only to human or animal cognition over all kinds of living systems. Another essential feature in this semiotic naturalism is the demand for semiotic realism - that signs are real and have real effects as signs and that this principle applies to every semiotic concept, i.e.,

(1) that at least some effects of signs are not reducible to physical (but are genuinely semiotic), and

(2) that the semiotic concepts are definable independently of our internal conceptions and intuitions about them, i.e. that semiotic concepts could be defined entirely at the 'object-level', from the point of view of 'object-system', (or 'object-agent' if the 'objectsystem' can be considered somehow agential, see Fig. 1).

In search for the proper concept of representation (or sign) for biosemiotics, we should first choose the proper motivation and 'prototype' for the concept in order to recognize what kind of conception is needed. There are at least three different motivations (accordingly, there are three basic 'prototypes') for the conception of representation: (1) representation for explanation 'how things are' (or for interpretation 'what is the essence of a phenomenon');

(2) representation for communication, or for explanation how the (mutual) communication of meanings (usually between individual human minds) is possible and mediated;

(3) representation for the guidance of appropriate behaviour, (i.e. for the anticipative behaviour), for the model of 'how things should be', i.e. for the model of the real reconstruction of the world; the 'real reconstruction' here includes both 'self-construction' and 'other-construction'.

An experience of a person is external experience if it refers to the object that is analogously sensible by others. An experience is internal, if it refers to (or is dependent on) some subjective object (or event) that is sensible by others only mediately through this internal experience. Naturalized concepts refer only to the objects of our external experience (Vehkavaara 2002: 295-297). 


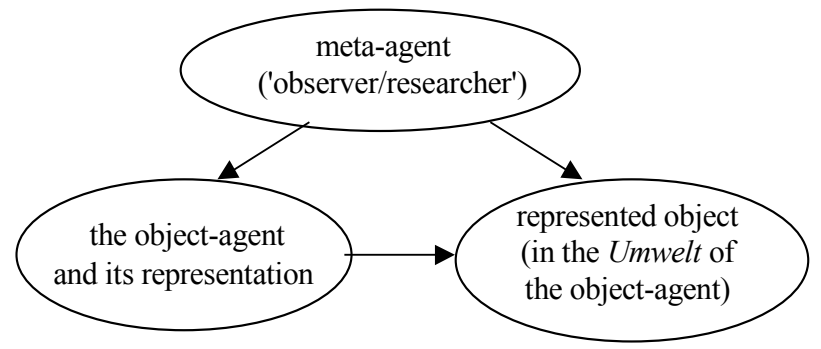

Figure 1. The phenomenology of the other one ${ }^{5}$ (Vehkavaara 2002: 300).

The explanative representation is familiar and widely used in science, art, and religion. It is self-evidently one of the basic concepts in philosophy of science. The communicative representation is a special case of the first one but the significant one, because it has been a central background conception in philosophy and human sciences after the 'linguistic turn' of the 20th century. It has dominated the basic orientation of both structural and cultural semiotics (Saussure, Lotman, etc.), as well as the ones of critical hermeneutics (e.g. Habermas) and the post-Wittgensteinian analytic philosophy of language and logical semantics. These two models or prototypes are not adequate starting points here. Firstly, most of the living systems do not explain anything (for themselves). Explaining is specifically human action, and even for humans, explanations are often made in the name of some (scientific, religious, medical, etc.) institution that has specialized to give such explanations. Secondly, although many living systems do (or are able to) communicate with each other (at least occasionally), all living systems (and especially the simplest and the most primitive ones) do not need to do that. Moreover, many living systems have to survive also when they are all alone, without any actual contact (even causal) with other systems. They have to deal with the challenges rising from their non-living environment without any aid or interaction with other systems. The 'private' use and formation of representations for the guidance of their behaviour and reproduction are necessary.

5 As an idea and a term, 'the phenomenology of the other one' (or 'the epistemology of the other one') is originated by Donald T. Campbell (1969). However, the more appropriately it should be called the logic or semiotic of the other one (cf. Vehkavaara, in preparation). 
Therefore, the third conception of representation, representation for the real reconstruction of the world is the starting point we need. It can be called the constructive or anticipative representation because of its orientation to future - it implicitly contains some kind of anticipation of the future reconstructions that it tends to produce. If we think about any externally determinable object-system (or -agent), the only hallmark of its act of anticipation is its apparently 'intelligent' or 'foresighted' control of behaviour. The constructive representation is familiar especially in politics and technology, but also in certain (mechanical) sense in genetics. ${ }^{6}$

The conception of constructive representation can be taken as the most general or primitive form of representation, because (A) the motivation behind the search of correct explanations is often the hope that this knowledge can somehow be useful. (B) In many cases, these anticipative representations can be and are used for communication too, i.e. as communicative representations. (C) If the basic hypothesis of biosemiotics holds that living systems are not essentially mechanical systems (but semiotic ones), the constructive representation is certainly the form of representation whose availability is necessary. Living systems have to reproduce themselves (if they are going to stay living), and for this self-reconstruction, some kind of internal 'guidebook' is needed. If genes, enzymes, hormones, etc. are considered as signs, most of them are principally signs in a sense of constructive representation, they function for the reconstruction of the system and its environment.

\section{Peircean objective logic and its insufficiency for biosemiotics}

The modern biosemiotics has dominantly been based on two different traditions, on Charles Peirce's semeiotic and on Jakob von Uexküll's $(1928 ; 1982)$ theoretical biology. In 'Copenhagen interpretation' of biosemiotics initiated by Jesper Hoffmeyer, some ideas drawn from these two traditions have been tried to consolidate and utilize in the

\footnotetext{
6 When a piece of DNA-string is said to be the gene of some trait, it is thought to represent (or code) that trait in the sense of anticipative representation - the occurrence of the gene is necessary for the construction of that trait in the organism.
} 
light of current biological and biochemical knowledge. Although both Peirce's semeiotic and Uexküll's Umweltforschung and Bedeutungslehre share a common antecedent, Immanuel Kant's transcendental philosophy, and both of them relativize and naturalize Kant's transcendental idealism in some respects, they nevertheless did not go very far in their 'naturalism'. Still, certain features make especially Peirce's semeiotic more than a promising starting point for the naturalization of its semiotic concepts.

Firstly, Peirce's concept of sign is general enough to support all the above described three different motives for the concept of representation. Secondly, Peirce's concept of mind suits more than ideally with the consequence of the basic hypothesis of biosemiotics: living systems are mental systems (and vice versa). If we think what makes the concept of representation or sign essentially mental, we find that it is ultimately some kind of normativity internal in it. Any interpretation, translation, or other transformation of signs can be judged successful or unsuccessful according to some normative criterion like the grade of fruition of the anticipated result of the process. According to Peirce, it is this normativity, purposiveness, or more generally, final causation in a sense of a general tendency that may or may not fulfill, which is the definitive character of mind or mental systems in the most general sense:

Mind has its universal mode of action, namely, by final causation. The microscopist looks to see whether the motions of a little creature show any purpose. If so, there is mind there. Passing from the little to the large, natural selection is the theory of how forms come to be adaptive, that is, to be governed by a quasi purpose. [...] But the being governed by a purpose or other final cause is the very essence of the psychical phenomenon, in general. (Peirce, CP 1.269 [1902])

Thus, mind can be found in any natural system whose action appears (quasi)purposive, and therefore, it can be studied as it appears in nature. No consciousness or free will is the necessary (or even common) companion of mind although both of them are real possibilities, their reality in certain phenomena is not denied. The scope of biosemiotics could then be determined as applied Peircean objective logic, as a theory of mind objectively operative in nature (cf. Vehkavaara 2002: 302-303). A summary of Peircean scheme of objective logic is represented on Fig. 2. 


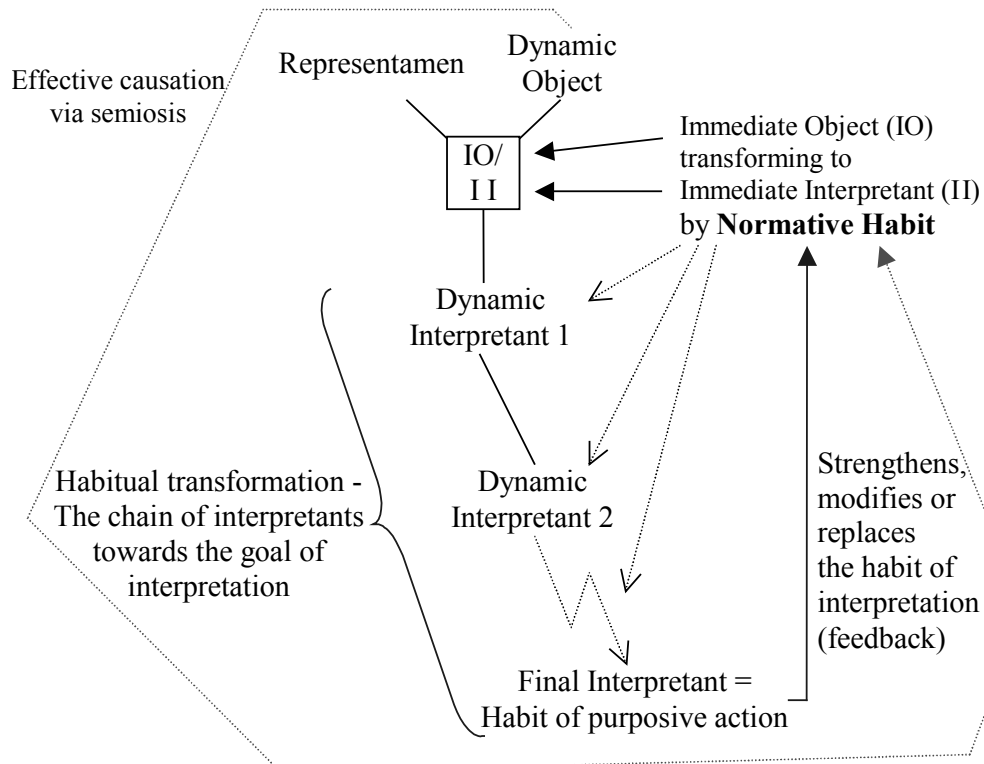

Figure 2. Peircean scheme of habituation.

Peirce defines a sign or representation as a non-reducibly triadic unity of representamen, object, and interpretant. The act of the recognition of a representamen as a sign of its object creates the interpretant (see Peirce, W3: 82-83 [1873]). There are two perspectives to the object: (1) the immediate object is the object as it is presented in the sign, and (2) the real or dynamic object can be considered as the hidden totality of past causes of the sign as an event to be the sign it happens to be. The dynamic object is always more or less absent or hidden in the sign, but it has to be in certain ways 'previously acquainted' for the system (cf. Peirce, CP 8.178-179 [1909]). The result of the interpretation is another sign, the interpretant that is representing the same object as the original one. This interpretant-sign is further interpreted so that the whole chain of interpretants proceeds. The process of interpretation is not just a simple succession of signs, but it is a (quasi)-purposive or goal-directed process - a representamen is recognized to represent its object by a normative habit of interpretation. This 'norm' in the habit gives the criterion for the success- 
fulness of the interpretive process - the interpretation may fail during its actualization.

The immediate result of the interpretation is called the emotional or immediate interpretant that appears as some kind of 'feeling', 'irritation', or 'excitement' in the system where the interpreting habit is embodied. The process of interpretation does not necessarily arise above this state of 'feeling', in which case the feeling just fades away and the system returns to its earlier state without any significant effects. If the process proceeds beyond that temporary state, it produces some real action, i.e. some directed internal restructuration or external action of the system. These are called energetic or dynamic interpretants of the sign and they act as signs themselves. The chain of interpretants is potentially endless (as in seemingly endless discussion about the existence of God), but it may as well achieve a kind of end, the final interpretant (or final logical interpretant). It is no more a sign in itself, but the form that the resultant action takes - it is a form of a habit that either strengthens, modifies, or entirely replaces the habit according to which the interpretation was originally executed. The dynamic object is therefore the effective cause of the sign at least in this way by becoming the effective cause of the habit of interpretation in habit formation. The process of interpretation, semiosis, is a process of self-control, a process of self-controlled habit-formation. ${ }^{7}$

7 This description of semiosis is based mainly on "Prolegomena to an Apology or Pragmaticism“" (Peirce CP 4.530-572, 1906) and chapter 28 in EP 2 (MS 318, 1907). In the latter one, semiosis is described as a thought process that starts from perception and ends up to totally internalized and embodied belief (i.e. habit of action) about the dynamic object of the perceived sign. "[W]e have to distinguish the Immediate Object, which is the Object as the Sign itself represents it, and whose Being is thus dependent upon the Representation of it in the Sign, from the Dynamical Object, which is the Reality which by some means contrives to determine the Sign to its Representation. In regard to the Interpretant we have equally to distinguish, in the first place, the Immediate Interpretant, which is the interpretant as it is revealed in the right understanding of the Sign itself, and is ordinarily called the meaning of the sign; while in the second place, we have to take note of the Dynamical Interpretant which is the actual effect which the Sign, as a Sign, really determines. Finally there is what I provisionally term the Final Interpretant, which refers to the manner in which the Sign tends to represent itself to be related to its Object" (Peirce, CP 4.536 [1906]). 
This scheme of habituation is plausibly applicable to most human and animal horizontal semiosis, ${ }^{8}$ as Peirce himself certainly thought. But its general biosemiotic applicability, e.g. to phytosemiosis (i.e. to semiosis in plants, cf. Krampen 1981; Kull 2000), to intracellular semiosis, to prokaryotic semiosis (Hoffmeyer 1997; 2002) and especially to vertical semiosis (i.e. to phylo- and ontogenesis, cf. Hoffmeyer, Emmeche 1991; Hoffmeyer 1996b) is more dubious. This concerns the application of Peirce's triadic concept of sign and especially the concept of object. The concept of semiosis should, perhaps, be defined in terms that are more general. Then the sign-action would be only a special type of semiosis, as Peirce himself seems to suggest. ${ }^{9}$ I nevertheless doubt that it is not justifiable to extend the concepts of sign or representation, its objects and interpretants, etc. so that they could be used to describe any such semiosis.

8 In 'Copenhagen interpretation' of biosemiotics, the term horizontal semiosis refers to systemic "communication throughout the ecological space" in contradistinction with vertical semiosis referring to "genetic communication down through the generations" (Hoffmeyer 1997b: 933).

9 'But by 'semiosis' I mean, on the contrary, an action, or influence, which is, or involves, a coöperation of three subjects, such as a sign, its object, and its interpretant, this tri-relative influence not being in any way resolvable into actions between pairs." (Peirce CP 5.484 [1907]. Cf. also Peirce's self-criticism in CP 1.565 [c. 1899].) However, there are some Peirce-scholars like Peder Voetmann Christiansen (2002), John Deely (1990: 83-92), and Edwina Taborsky who define both semiosis and sign in metaphysical terms. E.g. Taborsky (2002: 363) defines semiosis in terms of codification, energy, and informed mass.

10 Peirce himself does not seem to be quite consistent. This kind of extension of the concept of triadic sign would, at least, violate Peirce's "ethics of terminology" (Peirce EP 2:263-266 [1903]), but not merely the ethics of terminology speaks in favor of this interpretation. A comparison of Peirce's maxim of pragmaticism (e.g. Peirce CP 5.9) with his examples of sign-action that concern almost exceptionally about human agents, should lead to the same probable conclusion. Moreover, the most famous of the rare examples of non-human representations, the turning of a sunflower towards the sun (Peirce CP 2.274 [1903]), is used to demonstrate whether there are any genuine representamens that are not signs. If the concept of triadic sign is extended too far, there is a danger of a kind of 'overformalization' (as seems to be in Taborsky 2002) that the habits of inanimate nature are no more considered as strictly normative, but they are diluted to merely formative habits. This degenerated semiotic ceases to be a 'positive science' but it flows under the field of 'negative sciences' (as Peirce himself forewarns in CP 4.241). It becomes mere 'mathematics' in the sense that Peirce gives to it: "the Conditional or Hypothetical Science of Pure Mathematics, whose only aim is to discover not 
The general thesis in this paper is that, from the point of view of the interpreting system ('object-system'), the environment does not have to be divided into objects at all. At the metalevel, from the point of view of human observer (meta-agent), the environment of an object-system is divided into objects, but object-systems do not necessarily have access to this or any such division - they do not necessarily have any Umwelt. ${ }^{11}$ Interaction with the undivided environment (or more properly, within the whole local world that consists of both the object-system and its environment) is sufficient. This does not mean that the concepts of object, the whole Peircean triadic sign, and Umwelt were not real or applicable but that they are not properly applicable in all cases where meaning and final causes are present. They are not primitive semiotic concepts but emerge within relatively complex semiotic systems. The objects of representation step into the stage side by side with the emergence of real zoösemiotic (or perhaps also robosemiotic) Umwelt. This is well in line with the original use of the concept of Umwelt - for Jakob von Uexküll it was a zoological concept and he explicitly rejected the idea that it could be applicable to plants:

The plant has no nervous system, receptors, or effectors; therefore, no meaning-carriers, functional circle, perceptual, or effector cues exist for the plant. [...] The houses of plants lack mobility. Because they possess neither receptor nor effector organs, plants are not able to construct and be in command of an Umwelt. (Uexküll 1982: 33)

As Kalevi Kull (2000: 330-331) has noticed, Uexküll wrote almost nothing about plants in his Theoretische Biologie (Uexküll 1928) and other early writings. This does not nevertheless mean that there would not be meanings or even signs for plants, ${ }^{12}$ but whether there are any objects for plants is questionable.

how things actually are, but how they might be supposed to be, if not in our universe, then in some other" (Peirce CP 5.40 [1903]).

11 The concept of Umwelt, introduced by Jakob von Uexküll (1928), can be defined as a species-specific "subjective world of an organism" (Emmeche et al. 2002: 30). The Umwelt of a species of object-system is the environment (or more generally the world) as it is appearable for the object-systems according to their species-specific (sensory) capacities. The concept of environment is treated here as a meta-level concept, the environment of an object-system is externally determined (or defined) by the meta-agent, the observer or researcher.

12 Instead of Umwelt, Uexküll introduced the concept of Wohnhülle (dwellingintegument) for plants (Uexküll 1982: 34; discussed in Kull 2000: 330-332). 


\section{Implicit adaptationism in Peircean objective logic}

The object of sign/representation was, however, a necessary compound of sign for Peirce. It had a certain explanatory task - it was needed to explain the potential success of interpretation: the habit of interpretation is able to track the right object for the interpreted representation, because this object has already affected the formation of that habit in earlier semiosic processes. Especially in the context of scientific investigation, which was Peirce's central prototype for objective logic (cf. Vehkavaara 2002: 301), the concept of object is needed to provide both an initial contact with the real world and the criterion for the successfulness of the interpretation. The investigation is looking for the truth about the real object of the representation.

The problem is that as a general explanation of habit formation, this is in the certain respect parallel to the adaptationistic mode of thinking in sociobiology and functionalistic anthropology. The initial criticism of 'Panglossian adaptationism' (Gould, Lewontin 1979) attacks on two common assumptions: (1) natural selection is assumed to forge optimal — not just sufficient - adaptations, and (2) every identifiable common trait is implicitly assumed (or perhaps better, defined) to be a real adaptation, i.e. that nature has really selected it because of its advantageousness. The general form of the latter of these assumptions - with its practical consequence that only adaptive historical explanations are drawn - seems to be present also in the Peircean scheme of habituation. It is, namely, an explanation and description about how cognition, knowledge, or 'synthetic judgements ${ }^{13}$ are possible and how the knowledge acquisition or learning can be cumulative or otherwise positively progressive. And the explanation was that our habits of interpretation tend to interpret signs we are receiving correctly, since our habits of interpretation are already predetermined to do that because of the earlier influence of the objects of these signs. This is an adaptationistic a priori story if it is taken as the universal model of habit formation.

Both sociobiological (etc.) and semeiotic adaptationism seem to be based on the strong implicit (although simultaneously often explicitly rejected) intuition that there can be no event without a cause. This

13 While Kant started his Kritik der reinen Vernunft by asking 'how are synthetic judgements a priori possible', Peirce argued that "before asking that question he ought to have asked the more general one, 'How are any synthetical judgments at all possible?"' (Peirce CP 2.690 [1877]). 
claim may sound odd, because Peirce is so well known for his antinecessitarianism in cosmology (cf. "The Doctrine of Necessity Examined", Peirce EP 1: 298-311 [1892]). Still, although one of Peirce's basic metaphysical conceptions was that absolute or objective chance is real and effective force in every event, it was not meant to explain the regularities of phenomena but their inevitable irregular characters. ${ }^{14}$ The habits (of interpretation), if any, are regular phenomena and the possibility that some formation of a successful habit of interpretation could be completely accidental or unmotivated might seem to ruin the basic doctrine of the internal normativity of signaction. Namely, without an object of sign, any internal criterion for successfulness of an interpretation cannot be drawn - if there were any normativity in the interpretation, it would be completely external to the sign interpreted. Otherwise, there would be no directionality in habituation and interpretation.

Thus, for Peirce, appealing to chance probably did not appear as an intellectually satisfying explanation for the regularity of the successful habit formation. ${ }^{15}$ Similarly, Panglossian adaptationists feel it intolerable to leave the existence (or even usefulness) of some traits to remain unexplained, because the situation reminds them too much about (or leaves open space to) such intellectually unsatisfying supernatural explanations as 'God made it so'.

Nowadays it is quite commonly accepted that besides natural selection, there are also other natural forces in the evolution. Many life forms have useful or functional traits that are not selected because of their usefulness or functionality, but that are exapted. They have been adapted for some other function (which may not be functional anymore) or not adapted at all, e.g. when they are just consequences of some material constraints or genetic drift (Gould, Lewontin 1979; Gould, Vrba 1982). This thought is analogously applicable to general semiotics, and especially to biosemiotics, in which evolutionary adaptations have to be considered as useful habits of biosemiotic interpretations. All apparently useful traits or habits of behaviour do not

\footnotetext{
14 Continuously effecting chance was also needed to make the emergent development or creative evolution, i.e. the arousal of essentially new forms in nature possible.

15 Peirce rejects the explanations that appeal to miracles etc: "[A]n explanation should tell how a thing is done, and to assert a perpetual miracle seems to be an abandonment of all hope of doing that, without sufficient justification" (Peirce CP $2.690[1877])$.
} 
necessarily have adaptive origin, but their historical origins do not explain - or have anything to do with - their usefulness. Thus, if the object of sign is tried to determine in such cases, either it has not been attended in the formation of the interpreting habit or it has nothing to do with the successfulness ('goodness') of the interpretation. This does not mean that history would not matter. It does matter in many cases but not in all cases. But even in the cases in which the history is significant, it is often not known what were the particular historical forces in the development of an apparently useful trait or habit. In such cases the mere usefulness of a trait or habit does not give enough evidence to conclude that it is also designed (whether by self-organization or by natural selection) to be useful. It would be mere storytelling, which both Peirce, biosemioticians, and sociobiologists (among many others) have all tended to commit in some respects (cf. Gould 1978; Gould, Lewontin 1979).

Despite the problems due to its implicit adaptationist logic, Peirce's concept of representation is still a promising starting point. It is not merely an explanatory concept, but independently of its explanatory use, an anticipatory concept too. A sign or representation is not just looking at its past causes - it has no meaning or signification, i.e. it is not a sign at all, if it could not have future effects, if it is not able to direct future actions. What is needed is such a criterion (or norm) for the validity, value, appropriateness, or successfulness of the interpretation that is definable without any reference to the concept of the object of representation. After all, they are essentially the goals, norms, or purposes of action that make actions semiotic (or, in the generalized sense, 'mental'), and distinguish them from phenomena that are nothing more than physical. If there were no kind of goal, norm, or purpose in interpretation, there would be no criterion for the value of interpretation and there would be no real sense in calling this transformation process an interpretation or a sign process - nothing would distinguish it from a sheer physical process.

Now we are coming into the crucial point concerning semiotic naturalism. If any kind of normativity or teleology is somehow defined in natural terms, it offers, in a sense, some kind of positive solution to the one of the most central philosophical questions of modern era, how 'ought' can be defined in terms of 'is'. However, we must first make it clear what kind of normativity we are looking for. 
1. A naturalist cannot rely on or refer to anything supernatural, and even if naturalism would be taken only as a methodology, there cannot be any place for God or other supernatural forces in natural science. Naturalism endeavours to explain away the need for any supernatural or vitalistic principle in science (cf. Stjernfelt 2002: 342).

2. We are looking for a system relative concept. What does it mean if something is said to be beneficial for the system? Most of all, any normativity, criterion for progress or purpose is not supposed to be found for global evolution.

3. We need a real concept of a system relative normativity or "natural self-interest'. The success or unsuccessfulness of a system must have real effects in the world - success must, on the one hand, be externally observable phenomenon, and on the other hand, be effective independently of our human descriptions, definitions, and observations. It must give objective criteria for the value of the interpretations of a system for itself (i.e. independently of our human purposes, needs, interests, and ideas).

4. The concept is not necessarily representational for a system. Norms for action are only some kind of general guiding principles that need not be in any sense conscious any more than individual 'existing things' or 'Platonic ideas'. Goals, (purposes) or interests of a system are not necessarily in themselves represented at all in the system. ${ }^{16}$

There are numbers of notions (or words) that biosemioticians (and others) have used to refer to this distinguishing character of the semiotic realm. Among these are finality or final cause (e.g., Peirce, Hoffmeyer), purposefulness (e.g., Peirce; Hoffmeyer, Emmeche 1991; however, notice Hoffmeyer 2002: 102f), goal- or end-directness (e.g., Bickhard 1998), intentionality (Hoffmeyer 1996a), value (e.g., Sharov 1998), need (e.g., Kull 2000: 340), and appropriateness (e.g., Vehkavaara 1998). The list is certainly incomplete. In the standard neoDarwinism, the concepts of fitness (as 'reproductive success') and function have played the same role as the normative or teleological concepts of the list above.

16 This is in accordance with Peirce's 'extreme scholastic realism' that there are real generals (although not all generals are real, cf. Peirce CP 5.430, 1905) that are (like natural laws) not existing 'things' in the 'world of ideas' or anywhere else. Peirce's conceptual realism is Aristotelian rather than Platonic. 
Before the concepts of representation, its object, interpretation and Umwelt can be thoroughly considered, it is necessary to define the concept of 'real' system related normativity or natural self-interest. How the 'benefit for object-system' is definable at object-level and what is its origin or emergence in natural systems. I am proposing that the Peircean concept of triadic sign and Uexküll's concept of Umwelt are both definable in terms of Mark Bickhard's interactivism - that interactivism would offer more general (but not too general) and definite conceptual scheme to biosemiotics than either of these.

\section{Function and natural self-interest}

In Bickhard's interactivism, the naturalistic treatment of normativity, how 'ought' can be defined in terms of 'is', is based on the concept of function or (self)functionality. Marc Bekoff and Colin Allen (1995: 254) have classified three main accounts to the concept of function as follows.

1. The etiological or historical account. "A trait $T$ has function $F$ for the organism $O$ if $F$ was an effect of ancestral versions of $T$ that contributed, via natural selection, to transmission of $T$ from $O$ 's ancestors to $O$ " (Bekoff, Allen 1995: 254). The function of a trait or organ is defined according to its appropriate evolutionary origin. This is a backward-looking account. The concept of the etiological function is used when a historical explanation for the origin or 'becoming' of the existence of a trait in a given population is quested. The etiological concept of function can be successfully used in the explanations of how the systems have developed as they now are (e.g. Williams 1966; Gould, Vrba 1982).

2. The 'function as capacity' account. "A trait $T$ has function $F$ for organism $O$ if $F$ is an effect of $T$ that contributes to some capacity of $O$ ". This conception is neutral to all normative judgements about the function - no distinction between function and dysfunction can be made. "According to this account, it is just as much a function of blood to carry pathogens as it is a function to carry oxygen" (Bekoff, Allen 1995: 254).

3. The forward looking 'current utility' account. "A trait $T$ has function $F$ for organism $O$ if $F$ is an effect of $T$ that contributes to $O$ 's fitness. This definition is forward looking (dispositional) in the 
sense that function is defined with respect to future reproductive success" (Bekoff, Allen 1995: 254).

The 'capacity-account' is transparently unsuitable here, because we are looking for a normative concept. The etiological concept is heavily criticized by Bickhard being causally epiphenomenal: in the etiological model, the mere current state (or process) of a system is not sufficient to specify function, but the right kind of history is essential - still, only current state can be causally efficacious (Bickhard 1998a: 266). In interactivism, the concept of function is thus defined as a forward looking concept, which is, in a sense, a natural choice, because we are not trying to explain how this or that functional trait has emerged, but what is its future value to the system. ${ }^{17}$ However, we need more general definition than the 'organismal' one above organism does not necessarily fit well enough to what is counted as a living system here (cf. footnote 2 ).

The concept of function can be based on the property of the potential immortality of living systems - anything that contributes to the maintenance of a system is functional to that system. Because living systems maintain themselves far from equilibrium, the property of self-maintenance is an existential precondition of these kinds of systems. If any self-maintenant far from equilibrium system, the maintenance of which is based on its own activity, can no more serve this function, it starts to fall apart and will soon become extinct (i.e. it falls into some equilibrium state). In this way, we become able to say that serving a function of self-maintenance is a natural self-interest of any self-maintenant far from equilibrium system. It is not about the plain survival of a system, but about the survival of a system by means of its own activity, by its internal continuous flow. The self-interest for self-maintenance is not necessarily the only 'value' for the system (like Darwinian 'survival value') though still, perhaps, minimal natural self-interest. Additionally, it may set up new goals, 'values', or purposes as the system develops in its continuous self-organization. Moreover, living systems are not merely self-organized but also 'other-organized' by other living systems so that they may additionally function for alien goals, interests, etc. As these alien interests

17 This does not mean that the backward looking concepts of function were needless. Some of them are probably necessary to explain the course of past evolution. Both backward and forward looking concepts are useful, but they should be kept separated — they are suitable for explaining different issues. 
mix with self-interests, it may be impossible to make sharp difference between them. The self-interest for self-maintenance provides only initial normativity.

Notice firstly, systems that are not in far from equilibrium but in some (stable) 'energy well' — state do not need to maintain themselves - the 'successfulness' of their action is not their existential precondition. Therefore, there is no natural criterion of success for themselves (at the object-level) — a 'meta-agent' is needed for the definition of success. Similarly, such far from equilibrium systems that are not even indirectly self-maintenant but completely 'othermaintenant' do not have any natural self-interest either - the consequences of their action do not affect their maintenance. Secondly, every particular self-maintenant far from equilibrium system has its own natural self-interest(s), because "function, in this view, is always relative to a particular system - something might be functional for one system and simultaneously dysfunctional for another" (Bickhard 1998a: 266). Thirdly, there is no natural self-interest for the whole universe. Even if the universe might be considered as a far from equilibrium system, it is nevertheless questionable whether the universe needs to maintain itself. How could the universe be unsuccessful in its self-maintenance? If there is no possibility for failure, there is no natural criterion for success either. Thus, the local emergence of system relative normativity does not contain any assumption about the purpose, progress, or even direction in global or cosmic evolution.

\section{Primacy of normativity and function over habituation and signs}

The concepts of natural self-interest and function are not applicable only to living systems but to all non-living self-maintaining far from equilibrium systems. If this sounds counterintuitive or inappropriate, it will not need to do so. Although such non-living physical systems as a candle flame or a tornado are serving their self-interest and, as a consequence, are 'staying alive' (without being living), they are nevertheless not trying to serve it. Their self-interest is not forcing or 'suggesting' them to do anything. They are not seeking how they can survive but they just happen to have such a structure that fulfils their sole self-interest and existential precondition some period. Their self- 
maintenance does not yet give birth to any real growth or increase in complexity.

The situation is different if a system has alternative ways of selfmaintenance available and it can switch one alternative to another if the first one did not succeed. Bickhard calls systems of this kind recursively self-maintenant:

The conditions under which the serving of a function succeeds constitute the dynamic presuppositions of those functional processes. [...] Some systems, however, have the ability to switch among two or more means of being self maintaining, two or more functional processes, such that if the dynamic presuppositions of one fail, the dynamic presuppositions of the other may hold. (Bickhard 2001: 462)

Within the recursively self-maintenant systems - and living systems are certainly such - representation and internal error recognition (and consequently, 'pre-rational' choice) can emerge and the evolutionary growth becomes possible.

Before going deeper into recursively self-maintenant systems, I would like to propose that one basic 'chicken and egg' problem of biosemiotics (or semiotic naturalism) can now be resolved (cf. Emmeche 2000; 2002). If we look at the rise and development of biosemiotics in the 1990s, the point of view and solutions that especially its 'Copenhagen interpretation' have suggested to the problematic of the origin and emergence of life have been the main strength and legitimation of the biosemiotic approach (cf. Hoffmeyer 1996b; 2002; Hoffmeyer, Emmeche 1991). The potential impact of biosemiotics on the understanding about living phenomena is to demonstrate how the historical (evolutionary and developmental) and the structural ways of description can be inextricably conjoined, and if they are not seamlessly conjoined (as in mainstream biology), how their 'methodological' separation distorts the interpretation.

The standard biosemiotic solution that the thesis about the coextensivity of signs and life underlines, is that in the cosmic history, all the basic semiotic concepts have emerged simultaneously within the emergence of first living systems. But now, if we agree that there has been an era when life has not yet emerged, and that at that time, some self-maintaining far from equilibrium systems - like Kauffman's (1995) autocatalytic closures - have nevertheless been existed, we have to conclude that these systems, even if neither living nor representative ones, have already had real natural self-interests of their 
own. Natural self-interests and functions have emerged before life and signs (or representations) in the cosmic history. The norm of interpretation that makes the interpretation possible has become first (before any interpretation) and the actual interpretative systems have developed afterwards. Normativity, self-functionality, and self-interest are more primitive and general concepts than the ones of sign, representation, and interpretation are - they can be described and defined without any reference to the concepts of life and sign, they are properties of physical systems of a certain kind. The extension of living or genuinely semiotic systems is a subclass of the extension of systems with self-interest. ${ }^{18}$ However, there is still point to call the problem a 'chicken and egg problem', because although natural selfinterests can be said to have been emerged before life and semiosis, they have played no role in cosmic evolution until the emergence of recursively self-maintenant systems, i.e. of life and signs. They were 'insignificant', had no power over the course of evolution without the agent, without the living system that tends to fulfil its self-interest. Real final causes co-emerge with life and signs.

18 Although Peirce's classification of sciences (cf. Peirce CP 1.180-202) does not offer any cosmological order of concepts, it gives some support to the thesis about the primacy of norms or goals over signs. In this classification, Normative science (as the second order of Philosophia Prima) is divided into three 'families': esthetics, ethics (practics), and logic (semeiotic) (cf. Peirce, CP 1.281). Logic as the science of self-controlled thought is subordinate to ethics (and a subclass of it). Ethics, in turn, as the science of self-controlled action needs aid from esthetics in determining its ideals or goals, i.e. establishing its norms (Peirce, CP 1.191). Thus, in Peirce's system, the esthetic concepts like norm, goal, or purpose are more abstract than logical concepts like sign, representation, and interpretation. Norms can be studied without the concept of sign (at object-level), but signs and semiosis cannot be studied without the reference of some esthetic concepts (norms, goals, ideals, etc.) - or in terms of Peirce's 'method of precission' (cf. Peirce CP 1.549 [1867]), norms (etc.) can be prescinded from signs, but signs can not be prescinded from norms. I have elsewhere (Vehkavaara, in preparation) concluded that according to Peirce's classification of sciences, only minor part of biosemiotics can be properly characterized as applied semeiotic (i.e. logic) but rather applied ethics and esthetics (in Peircean theoretical sense). 


\section{There are a million ways to maintain oneself in the long run}

If a far from equilibrium system is recursively self-maintenant and thus may have alternative procedures for self-maintenance, then the future development of the system is dependent on which alternative, on which 'way of life', it chooses. Sometimes these 'choices' are irreversible as when recreating the basic material structure of the system and constraining thus all the future development. However, even if these irreversible 'choices' can not be cancelled, the construction of additional functional structures can compensate their inappropriate effects. In contrast, if the system fails in its maintenance, it is insignificant which way that happens, its causal effects, as well as semiotic ones (if it has any), end anyway. So, there is a kind of antisymmetry between failure and success, the meaning of total failure is absolute for the system, but one of success depends on the way of selfmaintenance. If the concept of representation can successfully be based on this concept of minimal natural normativity, the similar antisymmetry holds between the invalidity and validity of representation, between its inappropriateness and appropriateness, and between its falsity and truth. There is the absolute negative limit, extinction, but no necessary positive limit, because future growth and development is dependent on the successfully chosen way of self-maintenance.

The success in self-maintenance can be achieved by two basic strategies: by the manipulation of the system itself or of its environment. In variable external conditions, a system can maintain itself either 'directly', by self-reconstruction, i.e. by altering itself (as in adaptation to environmental pressures), or 'indirectly', by the active reconstruction of the local environment so that the altered environment would function for the maintenance of the system. These basic ways of self-maintenance do not exclude each other but are often carried through simultaneously and the distinction between them is not a sharp one, especially in cases where the self-maintaining activity operates in the borderline of the system and its environment.

For instance, (most) poikilothermic animals have only behavioural thermoregulation available. Their only way to maintain their optimal internal temperature (for self-maintenance) is to change the temperature of their environment. There are several possible ways for this 'environmental reconstruction'. An animal can exchange its environment for another one of a different locality, as in seasonal migration. It 
can also make 'real reconstructions' in its present local environment by building nests, digging tunnels, etc. Homeothermic animals have, in addition to behavioural thermoregulation, also means for metabolic thermoregulation that does not affect much on the environment but that function self-constructively. When metabolic heath production (as well as winter sleep or hibernation with decreased metabolism and internal temperature) is switched on, the organism is changing its own mode of action in order to fit better with changed environmental conditions.

\section{Self-reconstruction - choosing the 'way of life' and constructing new purposes}

Recursively self-maintenant systems are more complex than a simple candle flame or tornado. They contain subsystems the operation of which the whole system is maintained. When these subsystems take care the maintenance of the whole system, each of them functions in itself for some subgoal (like the maintenance of the optimal internal temperature of the whole system). If these subsystems are far from equilibrium systems, they have to be maintained either by the whole system (i.e. by other subsystems) or by the subsystem itself. In the latter case, a subsystem has its own self-interest of self-maintenance in addition to its functioning for the interests of the whole system. As the system develops and evolves, some goals of the subsystems may become independent of the goals of the whole system. They may even evolve in the pathological direction where the existential conditions of a subsystem and of the whole system are in conflict. Phenomena like cancer, mental illnesses, suicide, and many seemingly 'pathological' cultural tendencies (whatever they were) might be considered as examples of this kind of development and 'conflict of interests'. The self-reconstruction means thus either the creation or assimilation and integration of new subsystems within the whole system or the development of old subsystems to strive for new subgoals or 'needs' that some internal or environmental changes 'forces' the system to take into account. If newly created or assimilated subsystems are integrated, the whole system has to take account of their existential preconditions, i.e. the system has to begin to strive for the selfinterests of new subsystems. Thus, the self-reconstruction of a system means the adoption of new subgoals or purposes for the system, either 
by the system itself or by its environment. It is a kind of choosing the way of life - the choosing of the direction of (or some limits to) the evolution of the lineage.

\section{Reconstruction of environment - ecological implications}

(A) Passive reconstructions. Some of the effects, and even the most permanent ones, that living systems set off in their environment do not have much, if at all, to do with self-maintenance. They are not active reconstructions of environment but more like passive ones. The most obvious examples are coral limestone, coal-beds, and the other geological formations of fossil origin. These passive reconstructions of environment are 'side-effects' of a kind - if they happen to be functional, their functionality is purely accidental. They can not be considered as genuinely semiotic effects, but like the proportion of oxygen in the atmosphere, they may still be the most significant for current living systems.

(B) Active reconstructions. Reconstructions that are clearly designed (by the system) to be functional to the maintenance of a system can be considered as the genuinely semiotic effects of self-maintenance. By such active reconstructions of their environment, organisms (or living systems in general), in a sense, externalize their interests or purposes into their environmental structure. ${ }^{19}$ If this external structure is firm enough, these 'externalized purposes' may remain effectual even if they were no more functional to the system. The structures with externalized purposes may continue to strive for these purposes even after the extinction of the system.

The active reconstruction of environment can be divided into two branches: to the active reconstruction of non-living elements in the environment, and of the other (living) systems in the environment.

(B1) Active reconstruction of non-living elements in the environment. The most 'natural' examples of active reconstruction of nonliving elements are nest building (when it uses inorganic materials), the construction of coral reefs, etc. One of the most striking examples is nevertheless the machine construction of humans, and especially

\footnotetext{
19 The idea of externalized purposes is comparable with the concept of extended phenotype introduced by Richard Dawkins (1978)
} 
the creation of external non-living goal-directed or self-regulating devices and machines. When a (wo)man designs and builds machines, (s)he externalizes her/his purposes into the non-living material system that (s)he is currently organizing. This gives the sense in which thermostats can be said to be semiotic systems (although not genuine semiotic agents), as is proposed in the next chapter. A thermostat or any self-regulating system can be said to form representations that guide its functioning. It is a kind of representative system, but not a genuinely semiotic one, because the goals of its functioning are not of its own but set up by humans. It is functioning for human purposes. Mechanical man-made devices like thermostats do not have to maintain themselves, because usually they are not far from equilibrium systems. They have no self-interests - their existence as systems is not (necessarily) dependent on their action. The norm for their 'interpretations' (that distinguishes well-functioning from malfunctioning) does not contribute their maintenance.

(B2) Active reconstruction of other living systems in the environment - ecological implications: A system can manipulate other systems (that are in its environment) to maintain itself, to fulfill its self-interests, needs, or purposes that are in itself foreign to these other systems. However, this manipulation is not the necessary direct construction of other systems - other systems do not necessarily have to be in one's Umwelt as 'Other' (or at all). No direct contact between systems is needed. It is sufficient that only some of the effects (i.e. reconstructions) of other systems belong to one's Umwelt, (or if it has no Umwelt, to common environment) so that no genuine communication between systems exists. There is just a competition between the mutually exclusive reconstructions of the common environment. The one who 'loses' have to adapt oneself to the environmental reconstruction of the other system, i.e. to find new ways to maintain oneself. If this kind of indirect construction of other systems is reciprocal, it may bring along new symbiotic relations and a co-evolution of systems. ${ }^{20}$ It is at least logically possible that the emergence of symbiotic relations (or more generally, of heterogeneous metasystem

\footnotetext{
20 When one system forces the other one to adapt its reconstructions in their common environment, this other may develop oneself into such a form that it can reconstruct some other characters in their environment to which the first system has to adapt oneself. In such a way, they may start to maintain each other without any direct contact between them.
} 
transition $^{21}$ ) does not require direct contact between symbionts (although it may develop later).

However, in many biological examples about symbiotic relations, there is a direct contact between symbionts in such a way that at least for one system, the others are in one's Umwelt as independent semiotic systems. Then, we can talk about the genuine semiotic construction of other systems. This does not necessarily imply that there would be a genuine communication between systems, because the relation of semiotic construction does not need to be reciprocal. Besides symbiotic relations, all parasite-host -relations (including human breeding of livestock etc.) are also examples of semiotic construction of other systems. For genuine (reciprocal) communication between systems, such a community of systems, where each one has others in one's Umwelt (as systems of 'similar kind'), is required.

\section{Minimal interactive representation - a representation without the object}

One of the basic claims in Bickhard's interactivism approach is that within recursively self-maintenant far from equilibrium systems, the minimal concept of representation emerges. Although Bickhard (1998b) presents a ten-level hierarchy of different concepts of representation, there is no need to consider all its levels here. For the basic semiotic concepts, three levels suffice. The level of minimal (interactive) representation "constitutes a minimal emergence of ontological representationality" (Bickhard 1998b: 189). The level of phenomenal objects is needed for Peircean concepts of the object of sign, the iconic and indexical types of signs as well as Uexküll's concept of Umwelt. Finally, at the level of symbolic signs, symbolic signs emerge. Further levels, where e.g. genuine intersubjective communication (language) and self-awareness might emerge, are not considered here.

Although the emergence of system-relative normativity or natural self-interest is essential both in biosemiotics and interactivism, the origin and ontological status of the norm, goal, purpose, or interest, according to which representations are judged, is not relevant merely for the theory and concept of interactive representation. It is sufficient

21 About metasystem transition and its types, see Sharov 1999. 
that the concept of natural normativity (or self-interest) can be defined without any reference to the concept of representation and that the world can be said to contain such real natural interests that are influential independently of our knowledge and concepts. For any representative system, some kind of goal, norm, or purpose is necessary, but this does not have to be its own. Thus, we can consider representative systems with non-natural purposes and goals that are set up e.g. by humans and that are serving - or are planned to serve - human interests.

For instance, if the goal of a man-made mechanical thermostat is to keep up steady temperature, the fulfilment of this goal has generally no survival value for the thermostat itself (except perhaps indirectly), although it may be beneficial for the man. They can continue their existence without doing anything, i.e. their good functioning is not their existential precondition (although the assumed or anticipated good functioning by humans may be the necessary cause for their becoming into existence). Ultimately, this means a kind of 'overgeneralization' of the concept of representation beyond genuine semiotic systems and processes. But does that matter much? It just means that mere appearance of sign-like acting 'representations' is not sufficient to determine the semiotic realm. Additionally, real natural self-interests are demanded.

This kind of 'overgeneralization' of the concept of representation has several benefits. First, it gives a clear sense in which respects robots and other self-regulating devices are human-like (or life-like) and in which respects they are not. Robots can be considered, modelled, and developed as representative systems. Second, mechanical man-made representative systems can be considered as extensions of their constructor (or user), i.e. as newly constructed subsystems of human agent. This is quite natural point of view especially when devices produced by medical technology are considered - e.g. when a malfunctioning organ is replaced by such an artificial device that secures the (main) function of the organ.

Whether within a natural or non-natural goal, whether a far-fromequilibrium or equilibrium system, a minimal ontological representative system $(S)$ has to include a subsystem, a differentiator $(D)$, engaging in interaction with its environment $(E)$.

[T] he internal course of that interaction will depend both on the organization of the subsystem and on the interactive properties of the environment being interacted with. $[\ldots][T]$ he internal state that the subsystem $[D]$ ends up in 
when its current interaction ceases will depend on the environment that it has interacted with. Some environments $\left[E_{1}\right]$ will yield the same final state $\left[F_{1}\right]$, while other environments $\left[E_{2}\right]$ will (or would) yield a quite different final state $\left[F_{2}\right]$. The possible final states of such a subsystem, then, serve as classifications of the possible environments: each final state classifies all of the environments together that would yield that particular final state if interacted with. Each possible final state $\left[F_{i}\right]$ will serve as a differentiation of its class of environments $\left[E_{i}\right]$. (Bickhard 1998: 186)

However, this is not yet enough to define the possible final state of a differentiating subsystem to be a representation of the corresponding class of environments. What are needed more are indications to some goal-directed activity $\left(A_{i}\right)$ of the whole system (i.e. to some effectorsubsystem) that may provide feedback to the environment. This corresponds to representation at level 4 in Bickhard's hierarchy of representations (Bickhard 1998: 189-191).

This basic model can be applied to any goal-directed control system, even to such a simple system as a mechanical thermostat that is connected in a radiator (see Fig. 3). The interaction of the differentiating subsystem (temperature measuring device) of a thermostat with its environment indicates different activities (switch on or off heating) depending on the quality of the environment (the temperature). A thermostat makes the environmental representation and uses it when it is functioning to fulfil its goal (to keep up minimum temperature etc.).

The basic model of minimal interactive representation suits well also for the 'hidden prototype' of horizontal biosemiosis (cf. Emmeche 2000), the chemotaxis of Escherichia coli. (See the more detailed description of E. coli, e.g., in Hoffmeyer 1997a.) Coli bacteria move in the direction which offers more nutrient molecules rather than less. They do this by measuring the saturation of their transmembrane chemoreceptor-sites while they move and by transmitting the weighted result of this measurement to the flagellar motors that are coordinately moving the cell. The system of transmembrane chemoreceptors that is sensitive to nutrient-molecules (wherever its internal limits will be defined) is a natural candidate for the differentiator for E. coli. Relative saturation and non-saturation of these receptors (or in the 'internal ends' of the receptors, the corresponding binding of ligands) form the two possible final states of this differentiator. When an external nutrient concentration is increasing relative to the motion of a bacterium, receptors will keep on saturated, otherwise the degree 
of saturation of the receptors will diminish. Each of the final states indicates counter clockwise or clockwise flagellar movements respectively and these will make a bacterium either to move linearly or to tumble around itself.

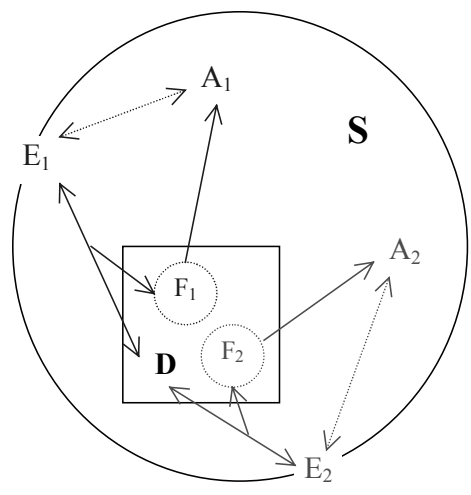

The case of $\mathbf{S}=$ Escherichia coli:

$\mathrm{D}=$ System of transmembrane chemoreceptors

$\mathrm{E}_{1}=$ Increasing concentration of nutrient molecules

$E_{2}=$ Decreasing concentration of nutrient molecules

$\mathrm{F}_{1}=$ Relative saturation of receptors in D

$\mathrm{F}_{2}=$ Relative non-saturation of receptors in D

$\mathrm{A}_{1}=$ Counter clockwise flagellar movement (leads to linear movement of S)

$\mathrm{A}_{2}=$ Clockwise flagellar movement (makes S tumble around itself)
$\mathrm{S}=$ Representative system,

$\mathrm{D}=$ Differentiator (differentiating subsystem),

$\mathrm{E}_{1}=$ Possible local environment 1 of $\mathrm{D}$ (alternative to $\mathrm{E}_{2}$ ),

$E_{2}=$ Possible local environment 2 of $\mathrm{D}$ (alternative to $\mathrm{E}_{1}$ ),

$\mathrm{F}_{1}=$ Final state 1 of $\mathrm{D}$ (alternative to $\mathrm{F}_{2}$ ),

$\mathrm{F}_{2}=$ Final state 2 of $\mathrm{D}$ (alternative to $\mathrm{F}_{1}$ ),

$\mathrm{A}_{1}=$ Activity 1 of $\mathrm{S}$ (alternative to $\mathrm{A}_{2}$ ),

$\mathrm{A}_{2}=$ Activity 2 of $\mathrm{S}$ (alternative to $A_{1}$ ),

$\longrightarrow=$ Indication, $\leftrightarrow$ = Interaction.

The case of $\mathbf{S}=$ thermostat

(connected in radiator):

$\mathrm{D}=$ Thermometer or temperature sensor

$\mathrm{E}_{1}=$ Environmental temperature below the goal-temperature

$\mathrm{E}_{2}=$ Environmental temperature above the goal-temperature

$A_{1}=F_{1}=$ Switch on heating

$A_{2}=F_{2}=$ Switch off heating

Figure 3. Basic model of minimal interactive representation.

Although both thermostats and coli bacteria are representative systems, thermostats (like the most of the man-made self-regulating machines) are not alive in any sense unlike E. coli. The difference between these is not based on the nature of the representation they are using but on the nature of the goals they are pursuing. Unlike thermostats, coli bacteria are real far from equilibrium systems and have to maintain themselves continuously thus having the natural selfinterests of their own. The open question arises: is it sufficient to 
characterize living systems — or (bio)semiotic agents — as minimal representative systems with at least one 'own' natural self-interest? Or are these merely necessary conditions?

\section{Some characteristics of the model}

1. Formality of the model. The interactivism offers only a formal model for the most primitive real representation. The counterparts in real systems have to be identified separately in each case. For instance, a differentiator need not be spatially differentiable 'organ' in the whole system, but it can be integrated in a distributed manner into the system.

2. Constructivism. The representations, the possible final states of the differentiator, are not continuously existent things. In this most primitive type of real representation, representations are not like already written letters or stable DNA-segments that are just waiting to be read and interpreted. Instead, their construction is repeated in every interaction/interpretation again by the differentiator (or by the interaction between the differentiator and its environment). They are permanent only as possibilities, not as existing states.

3. Internality of representations. Consequently, minimal representations are internal states of the system - they are not stable external things or objects that are just waiting to be perceived. Still, these final state representations are not purely internal or 'solipsistic' constructions of the system, but they are constructed in interaction with the environment so that they are produced in contact with the environment.

4. No objects of representations. Therefore, for the system there are no objects any more than the qualities of objects in its environment. All that a simple thermostat 'perceives' is the type of the environment it is interacting with. They are we, humans (who use thermostats) who can say that a thermostat measures the temperature and compares the measured value with its goal- or limit-temperature. Concepts as temperature and object are human concepts - they belong to human Umwelt and thermostats have no access to them. Thermostats have no Umwelt at all.

If $E$. coli bacteria were as simple systems as thermostats are, the situation might be the same for them as for thermostats, i.e. there would be no represented objects for them - bacteria 'recognize' only 
the type of the environment, not the nutrient molecules, and respond with the appropriate strategy. However, depending on the details of the bacterial representation processing, they may turn out to be complex enough so that bacteria can be said to perceive the objects i.e. that nutrients (molecules or the gradients of their concentrations) appear as objects to them - and to give an appropriate interpretation of the interactively constructed internal representation of these objects.

5. Objective error and internal error-detection. It is important to notice that goals or interests do not have to be represented in the system. A mechanical thermostat has no self-interest, there is no goal for the thermostat itself (although there is for the man), and in the case of a bacterium whose ultimate self-interest is just self-maintenance, the interest is not represented either, life or death is the criterion for the success. Thus, it is not circular to define the concepts of function, self-interest, and goal first, and the concept of representation afterwards.

In the recursively self-maintenant far from equilibrium systems, minimal interactive representations guide the goal-directed activity, and that guidance can be appropriate or erroneous - to be in error does not undress the representationality of the representation. Moreover, the system might even have means to find out that its representation is in error at this same level of minimal interactive representation. There is not only the possibility of error per se, but the possibility that the system might discover that it is wrong. "Specifically, if the system fails to reach its goal, then something was in error in the indications of further interactions for that goal, and, since that failure to reach its goal is itself an internal condition of the system, information of such failure is functionally available to the system for further processing" (Bickhard 1998b: 190).

Consider, as an example, the case of the so called alarmones, the bacterial signal molecules that signal stress (like glucose starvation), discussed e.g. by Gordon Tomkins (1975) and Jesper Hoffmeyer (2002: 111-112). When, say, saccharin molecules block the chemoreceptors of a bacterium, the bacterial system erroneously interprets the situation as if the glucose concentration is still increasing. The bacterium keeps on swimming linearly although it does not catch its primary nutrient, glucose, enough by doing so. If the bacterium had no other means to ensure its energy production, it would starve to death. However, in glucose starvation, when there is no glucose in the cell, the same enzyme (glucose kinase) that starts the process of glucose 
degradation starts its minor side reaction (because of the privation of the substrate of its main reaction), to degrade ATP to cyclic AMP (cAMP). ${ }^{22}$ Because cAMP and ATP tend to bind to the same regions of cellular proteins, the increasing concentration of cAMP leads up to increasing displacement of ATP from its normal binding sites. Therefore, since ATP is the major energy-carrier molecule of the cell, this process blocks effectively the energy consumption of the cell. This blocking effect on energy consumption is, in the situation like this, self-functional to the bacterial system. It gives more time to the system to detect the apparent error in the interpretive process that guides the chemotaxis (i.e. movements) of the system. The earlier dysfunctional indication (straightforward moving) of chemoreceptorsubsystem is blocked off by switch in energy-consumption-subsystem. The energy-consumption-subsystem 'detects' and even compensates 'detected' errors in chemoreceptor-flagellar-subsystem. Production of cAMP-molecules (from ATP) is a way of controlling the behaviour that is already controlled by other subsystems.

The description above is a somewhat speculative story about the evolutionary origin of the production of cAMP. The increasing concentration of cAMP is here a mere side-product of an errordetection process, but such a side-product that appears to correlate with errors in chemotaxis. Nowadays, bacterial systems use the increasing concentration of cAMP as an 'alarm-sign' of their internal state of glucose-starvation so that cAMP is used as a release-sign for specific transcription processes of the production of a series of enzymes needed for the degradation of non-glucose sugars. If the story about the origin of cAMP-production is correct, it is plausible to assume that the bacterial systems have learned - in the course of evolution - to 'cognize' the positive correlation between cAMP and starvation, ${ }^{23}$ and even developed additional methods of getting out of

22 The main reaction catalyzed by glucose kinase is

$$
\text { ATP }+ \text { glucose } \rightarrow \text { ADP }+ \text { glucose-P }
$$

and the minor side reaction is

$$
\text { ATP } \rightarrow \text { P-P + cAMP }
$$

where ATP $=$ adenosine-tri-phosphate, $\mathrm{ADP}=$ adenosine-di-phosphate, $\mathrm{AMP}=$ adenosine-mono-phosphate, and P-P = pyrophosphate (Hoffmeyer 2002: 111).

23 The high concentration of cAMP has become a sign of its correlate (starvation) for the bacterial system, which fits well in Hoffmeyer's 'rule of thumb' of biosemiotics: "Wherever there has developed a habit there will also exist an organism for whom this habit has become a sign" (Hoffmeyer 1997b). 
that undesirable state. I.e. when glucose starvation is detected, the production of the means for an alternative energy production system is launched and after that, the original interpretation-error in chemotaxis may no more appear dysfunctional, i.e. erroneous, for the system. ${ }^{24}$ It is noticeable that even if this evolutionary story were incorrect, it shows that minimal interactive representation is all that is needed for these kinds of switches in behaviour. Error of reaching a goal can be detected and compensated by other differentiators at the level of minimal interactive representation.

\section{Emergence of the objects (of representation) and Umwelt}

If we consider the basic concepts of Peirce's semeiotic, some of them have equivalents in the above described minimal interactive representative system. Most notably, the normal behaviour of a differentiatoreffector subsystem $\left(D+\right.$ the set of potential $A_{i}$ 's in Fig. 3$)$ constitutes a systemic habit, each final state $\left(F_{i}\right)$ of a differentiator $(D)$ constitutes the representamen of a sign, and indicated action $\left(A_{i}\right)$ of the system constitutes the (dynamic) interpretant of a sign. Because there is no object of a sign (for the system), signs can not be characterized either iconic, indexical, or symbolic. ${ }^{25}$ However, the concept of phenomenal object is still a real one, and the structure of systems that experience phenomenal objects - and that can thus have Umwelt and triadic signs - can be defined on the basis of minimal interactive representation.

A representative system can contain several interlinked differentiators and several different goals. Indications based on one final state of one differentiator can be multiple — which one will be chosen can

\footnotetext{
24 After these developments, these supposed original means of producing cAMP (as a side-product) has become dysfunctional for the system. The lowering of activity is no more needed, if these non-glucose sugars that block the chemoreceptors really prove to be eatable.

25 These constitute the possible relations that a triadic sign has with its real (or dynamic) object. Because in this minimal model there are the equivalents of the representamen and the (dynamic) interpretant, at least some equivalents of the other Peircean sign-types (based on the possible relations between a sign and its representamen and between a sign and its interpretant) might, perhaps, be detectable.
} 
be dependent on other differentiators and the success in reaching other goals. In such a complex representative system, the internal processing time of a system may become too long for fast enough checkings of the environmental conditions. For such a system, it may be profitable to create and maintain a set of standard or 'defaultsettings' of activity indications and to keep them updated ongoingly. These 'defaults' are then available if needed, without time-taking computation or processing of final states and indications to further actions at that time (the level 6 in Bickhard 1998: 194). An organization of the indications of interactive potentialities based on these defaults forms a kind of situation image that is used as a base for interaction while the continuous updating of its default-settings (apperception) is alienated to an independent process.

The updating process of the situation image leaves great parts of it untouched, so that there are certain temporal invariances in the situation image. If the system is able to discover such types of organizations of interactive potentialities in its situation image that tends to remain constant, unchanged or invariant as patterns with respect to the most potential updates of the situation image, then these invariances constitute something like objects for the system itself. Physical objects are then epistemologically, i.e. as they are accessible to the system, the "invariances of patterns of potential interactions under certain classes of physical interactions" (the level 7 in Bickhard 1998: 197).

Within this level of complexity, appears the emergence of certain biosemiotically central concepts. I suggest that both Peirce's and Uexküll's biosemiotic concepts presuppose this level.

1. Memory and perception. Discovering temporal invariances in the situation image constitutes a system memory and makes active remembering possible. Past 'experiences' can be reconstructed and the actual updates of the situation image ('actual experiences') can thus be identified with the past ones - objects and their invariant relations can be identified and recognized over and over again. Within memory and possibility to recognition, genuine perception emerges or becomes at least possible - perception which presupposes at least some kind of recognition and therefore also memory. ${ }^{26}$

26 Two forms of memory (and perception) emerge: one of environmental continuities and the other of internal system flows of activity (Bickhard 1998b: 197). Although 
The conception about perception is in coherence with Peirce's conception (see his Harvard lectures, 1903 on Pragmatism, CP 5.14212). Individual things or objects (including external signs), like individual persons, are not perceived directly as individuals. They are directly perceived, but if the different reacting perceptual singulars are to be identified as one individual object or other invariance, some kind of general character have to be associated with them. Thus, our common sense individual objects etc. are not 'singular existent things' but semi-instinctively derived general notions, relations of identity between singular perceptual reactions (cf. Peirce, EP 2: 222 [1903]).

At the level of minimal representation, there are just classes of environments - at the level of objects, invariant features of different classes of environments are constructed and differentiated from each other.

2. Umwelt and triadic sign. As phenomenal objects and percepts emerge the first time at this level of complexity, and especially because they are not external to the system but constituted as its internal states (although not without contact with its exterior) - they can be said to constitute the Umwelt for the system. Similarly, the simplest types of Peircean triadic sign or representation becomes applicable at this level. In my criticism of application of Peircean concept of sign in biosemiotics, the concept of the object of sign was troublesome. Now we have objects constructed by the system itself (in interaction with its environment, however) and internal to the system - immediate objects of signs can emerge.

3. Iconic and indexical signs. Within the ability to 'experience objects', i.e. to discover invariances in the situation image, the system becomes able to discover also invariant relationships between these invariances, as causal, similarity, part whole, and nearness (i.e. spatial) relations between objects. Especially, a system can remember the objects it has perceived in the past and find them in some respects

both of these forms of perception are internal states of the system, the difference between them constitutes the difference between external and internal experience (cf. Vehkavaara 2002: 295-296). The difference lies in the interacting environments: the perception about environmental continuities constitutes the external experience in which the interacting environment is at least partly exterior to the system boundaries. Consequently, the interacting environment in the perception of the activity history of the system is internal to the system and so it constitutes internal experience. 
similar to a new perception. Likenesses can be recognized which makes it possible that this new perception is cognized as the iconic sign of the objects perceived in past. Similarly, because also causal and other real relations (like nearness) between objects become recognizable, a system becomes able to handle indexical signs. ${ }^{27}$

Although I have suggested earlier (in this paper and in Vehkavaara 2002: 306-307) that no higher level than the one of minimal interactive representation is necessary for bacterial chemotaxis, it remains still somewhat open question. The more detailed biochemical descriptions are needed to resolve the question, whether the bacteria as real systems function at some higher level of complexity and after all construct internal objects. Or, perhaps we can say that bacteria have some kinds of situation images without ability to discover its invariances (like objects). Moreover, if this possibility is confirmed, we can raise a question: did the most primitive real living systems emerge already at that level or did some lower one suffice?

\section{Emergence of symbolic sign}

Although the concepts of Umwelt and iconic and indexical signs have now found their place and proper interpretation in the theory of interactive representation, no symbols, no language, no genuine social communication, and no self-awareness can yet be introduced. More complex levels of representation are needed for each of these. A corresponding situation occurs in Peirce's semeiotic, e.g. when symbolic signs are considered, they are defined as more developed than iconic and indexical ones, moreover, symbolic signs may have icons or indexes as its constituents (Peirce CP 2.261, 293 [1903]). I will consider only symbolic signs ${ }^{28}$ here in order to make complete the most widely used trichotomy in Peirce's semeiotic: division of signs into iconic, indexical, and symbolic.

27 Iconic signs are representations that are based on the recognition of a similarity between the representamen and the object of representation. Correspondingly, indexical signs are based on the knowledge or recognition of causal or other real relation (like nearness) between the representamen and the object of sign.

28 Symbolic signs are representations in which the relation of the representamen with its object is based merely on the habit that the representamen is used to represent its object, i.e. merely on the fact that the representamen is habitually interpreted as that particular sign. 
A system may have separate situation images for activities of a different kind that it uses in order to reach it goals. Each situation image has a direct 'on-line' effect into some activity. However, the environmental information that is gathered for one activity, may not be available for another activity, ${ }^{29}$ it may, for instance, be in an inappropriate form. The system can, however, create a 'second order situation image' that does not refer to environment directly but by the mediation of directly functional situation images. (This constitutes the level 8 in Bickhard 1998b.) The representations of this abstract situation image are alienated from 'direct' connect to their environmental referent, and this makes 'theoretical', vicariate, or 'off-line' processing of representations possible.

If we consider symbolic signs, the only property that makes a symbolic sign represent its object is that it is just used to represent it - that there happens to be such a habit. Now, the invariances in the relation of 'second order situation image' and directly functional situation images can be just such postulated habits (although they need not be). Thus, the symbolic representation and symbolic signs emerge. Still, these 'symbols' are purely internal to the system, they may be kind of 'private' symbols for the system - whether the genuine intersubjective communication of symbols (language) can be based on this or some higher level is not settled. ${ }^{30}$ For this, at least a community of systems is needed, the systems of which may need to have more complex or specialized internal structure. ${ }^{31}$

29 For instance, according to Konrad Lorenz (1941), water shrew has separate spatial maps for hunger, thirst, escape from each predator, etc. The spatial information that is saved in 'hunger-map' may not be available when it is thirsty and seeking water etc.

30 On the other hand, even at the lower levels, there are certainly reciprocal interaction and interdependence between systems. This is communication of a sort, but here the term 'communication' is used in a narrower sense referring to interaction where some content is intended to transfer to other systems. In genuine communication between systems, a message is sent that is supposed (by the sender) to be received and interpreted in some certain sense (by the receiver).

31 Acknowledgements. This paper is partly based on the presentation given in Gatherings in Biosemiotics 2, 14-17.6.2002, Tartu, Estonia. I would like to thank the organizers and participants of that meeting and specifically Jesper Hoffmeyer, Kalevi Kull, Stefan Artmann, and Mika Renvall whose comments and criticism have helped me to improve the earlier versions of this paper. Thanks are also due to the University of Tampere and Finnish Cultural Foundation for financial support during the preparation of this paper. 


\section{References}

Bekoff, Marc; Allen, Colin 1995. Teleology, function, design and the evolution of animal behaviour. Trends in Ecology and Evolution 10(6): 253-255.

Bickhard, Mark H. 1998a. A process model of the emergence of representation. In: Farré, George L.; Oksala, Tarkko (eds.), Emergence, Complexity, Hierarchy, Organization (Selected and edited papers from ECHO III). (Acta Polytechnica Scandinavica 91.) Espoo: Finnish Academy of Technology, 263-270.

- 1998b. Levels of representationality. Journal of Experimental and Theoretical Artificial Intelligence 10(2): 179-215.

- 2001. Function, anticipation, representation. In: Dubois, D. (ed.), Computing Anticipatory Systems: CASYS 2000 - Fourth International Conference. Melville: American Institute of Physics, 459-469.

Campbell, Donald T. 1969. A phenomenology of the other one. In: Campbell 1988: 337-359.

- 1974. Evolutionary epistemology. In: Campbell 1988: 393-434.

- 1988. Methodology and Epistemology for Social Science: Selected Papers. (Overmann, E. Samuel, ed.) Chicago: University of Chicago Press.

Christiansen, Peder Voetmann 2002. Habit formation as symmetry breaking in the early universe. Sign Systems Studies 30(1): 347-360.

Dawkins, Richard 1978. Replicator selection and the extended phenotype. Zeitschrift für Tierpsychologie 47: 61-76.

Deely, John. 1990. Basics of Semiotics. Bloomington: Indiana University Press.

Emmeche, Claus 2000. Closure, function, emergence, semiosis and life: The same idea? Annals of the New York Academy of Sciences 901: 187-197.

- 2002. The chicken and the Orphean egg: On the function of meaning and the meaning of function. Sign Systems Studies 30(1): 15-32.

Emmeche, Claus; Kull, Kalevi; Stjernfelt, Frederik 2002. Reading Hoffmeyer, Rethinking Biology. Tartu: Tartu University Press.

Gould, Stephen Jay 1978. Sociobiology: The art of storytelling. New Scientist 80: 530-533.

Gould, Stephen Jay; Lewontin, Richard C. 1979. The spandrels of San Marco and the Panglossian paradigm: A critique of the adaptationist programme. Proceedings of the Royal Society of London B 205: 581-598.

Gould, Stephen Jay; Vrba, Elisabeth S. 1982. Exaptation - a missing term in the science of form. Paleobiology 8(1): 4-15.

Hoffmeyer, Jesper 1995. The semiotic body-mind. In: Tasca, Norma (ed.), Essays in Honor of Thomas A. Sebeok. Porto, 367-383.

- 1996a. Evolutionary intentionality. In: Pessa, E.; Montesanto, A.; Penna, M. P. (eds.). Proceedings from The Third European Conference on Systems Science, Rome 1996, Rome: Edizioni Kappa, 699-703.

- 1996b [1993]. Signs of Meaning in the Universe. [En Snegl På Vejen: Betydningens naturhistorie, 1993; Haveland, Barbara J., transl.]. Bloomington: Indiana University Press.

- 1997a. Semiotic emergence. Revue de la Penseé d'Aujourd'hui 25-7(6): 105-117. [In Japanese; citations from English version.] 
- 1997b. The global semiosphere. In: Rauch, Irmengard; Carr, Gerald F. (eds.), Semiotics Around the World. Proceedings of the Fifth Congress of the International Association for Semiotic Studies. Berkeley 1994. Berlin: Mouton de Gruyter, 933-936.

- 1997c. The swarming body. In: Rauch, Irmengard; Carr, Gerald F. (eds.), Semiotics Around the World. Proceedings of the Fifth Congress of the International Association for Semiotic Studies. Berkeley 1994. Berlin: Mouton de Gruyter, 937-940.

- 1998. Biosemiotics. In: Bouissac, Paul (ed.), Encyclopedia of Semiotics. New York: Oxford University Press, 82-85.

- 2002. Code duality revisited. S.E.E.D. Journal 2(1): 98-117. (http://www.library.utoronto.ca/see/SEED/Vol2-

1/Hoffmeyer/Hoffmeyer.pdf).

Hoffmeyer, Jesper; Emmeche, Claus 1991. Code-duality and the semiotics of nature. In: Anderson, Myrdene; Merrell, Floyd (eds.), On Semiotic Modeling. Berlin: Mouton de Gruyter, 117-166.

Kauffman, Stuart 1995. At Home in the Universe. The Search for Laws of Complexity. London: Penguin Books.

Krampen, Martin 1981. Phytosemiotics. Semiotica 36(3/4): 187-209.

Kull, Kalevi 1999a. Biosemiotics in the twentieth century: A view from biology. Semiotica 127(1/4): 385-414.

- 1999b. On the history of joining bio with semio: F. S. Rothschild and the biosemiotic rules. Sign Systems Studies 27: 128-138.

- 2000. An introduction to phytosemiotics: Semiotic botany and vegetative sign systems. Sign Systems Studies 28: 326-350.

Lorenz, Konrad 1983 [1941]. Kant's Lehre vom apriorischen im Lichte gegenwärtiger Biologie. In: Lorenz, Konrad; Wuketits, F. (eds.), Die Evolution des Denkens. München: Piper 1983, 95-124.

- 1987 [1973]. Die Rückseite des Spiegels. 9. Aufl. Deutscher Taschenbuch Verlag.

Peirce, Charles S. 1931-1935, 1958. Collected papers of C. S. Peirce. Vols. 1-6 (Hartshorne, Charles; Weiss, Paul, eds.); vols. 7-8 (Burks, Arthur W., ed.). Cambridge: Harvard University Press. [Cited as CP.]

- 1992, 1998. Essential Peirce. Selected Philosophical Writings. Vols. 1-2. (Hauser, Nathan et al., eds.) Bloomington: Indiana University Press. [Cited as EP.]

Sharov, Alexei 1998. From cybernetics to semiotics in biology. Semiotica 120(3/4): 403-419.

Stjernfelt, Fredrik 2002. Tractatus Hoffmeyerensis: Biosemiotics as expressed in 22 basic hypotheses. Sign Systems Studies 30(1): 337-346.

Taborsky, Edwina 2002. Energy and evolutionary semiosis. Sign Systems Studies 30(1): 361-381.

Tomkins, Gordon 1975. The metabolic code. Science 189: 760-763.

Uexküll, Jakob von 1928. Theoretische Biologie. (2. gänzl. neu bearb. Aufl.) Berlin: Springer.

- 1982 [1940]. Theory of meaning. [Bedeutungslehre, 1940; Stone, Barry; Weiner, Herbert, trans.] Semiotica 42(1): 25-82. 
Vehkavaara, Tommi 1998. Extended concept of knowledge for evolutionary epistemology and for biosemiotics. In: Farré, George L.; Oksala, Tarkko (eds.), Emergence, Complexity, Hierarchy, Organization (Selected and edited papers from ECHO III). (Acta Polytechnica Scandinavica 91.) Espoo: Finnish Academy of Technology, 207-216.

- 2002. Why and how to naturalize semiotic concepts for biosemiotics. Sign Systems Studies 30(1): 293-313.

- (in preparation). Biosemiotics as applied objective ethics and esthetics (rather than semeiotic)?

Williams, George C. 1966. Adaptation and Natural Selection. Princeton: Princeton University Press.

\section{Естественный интерес, интерактивная репрезентация и формирование объектов и умвельта: определение главных семиотических понятий в рамках биосемиотики}

Жизнь и жизненные проявления в биосемиотике описываются с помощью семиотических понятий, которые по происхождению своему антропоморфны. Это могло бы быть оправдано, если бы мы могли доказать, что живые системы как самосохраняющиеся далекие от равновесия системы создают и обновляют своего рода репрезентацию, информацию об условиях своей сохранности. Это - точка зрения семиотического реализма, в котором знаки и репрезентации рассматриваются как реальные и объективные явления природы, не нуждающиеся в интерпретаторе-человеке. В статье утверждается, что основное определение репрезентации должно быть более дальновидным и что понятие знака как у Пирса, так и у Юкскюлла предполагает наличие слишком усложненного семиотического посредника. Простейшие репрезентирующие системы вообще не имеют явных объектов и умвельта. В качестве альтернативы выдвигается предложение основывать элементарное понятие репрезентации и источника нормативности, необходимого для ее интерпретации, на интерактивности М. Бикхарда. Первичная нормативность или естественный интерес опирается на концепцию "полезности" функции: все, что входит в комлекс сохранности нестабильной системы, является функциональным для этой системы, - каждое проявление самосохранения нестабильной системы обладает чертами минимального естественного интереса, это ее экзистенциалное непременное условие. Минимальная интерактивная репрезентация проявляется, если подобные системы могут соответствующим образом переключаться с одного на другой или большее количество модусов самосохранения. На уровне такой репрезентации мы можем выявить ошибки, даже если система не имеет объектов репрезентации. Явно выра- 
женные объекты проявляются в более сложных системах. Если система создает ряд постепенно обновляющихся "образов ситуации” и способна определить временные промежутки в этом процессе обновления, то в таком случае эти инварианты создают объекты для самой системы. Репрезентируемая таким образом система образует умвельт и делает возможным применение триадических знаков. Отношение между реперезентацией и ее объектом на этом уровне может быть либо иконическим либо индексиальным. Как в семейотике Пирса, так и здесь символические знаки появляются как более развитые: знаки-символы нуждаются в более сложных системах.

\section{Loomulik huvi, interaktiivne esitus, objektide ja omailma kujunemine: peamiste semiootiliste mõistete piiritlemine biosemiootika jaoks}

Elu ja elunähtusi on biosemiootikas kirjeldatud päritolult antropomorfsete semiootiliste mõistete abil. See oleks õigustatud, kui õnnestub tõendada, et elussüsteemid kui ennastsäilitavad tasakaalukauged süsteemid loovad ja täiendavad mingeid esitusi oma püsimistingimuste kohta. See on semiootilise realismi vaatekoht, mille kohaselt märgid ja esitused on reaalsed ja objektiivsed loodusilmingud, ilma tarviduseta inimtõlgendaja järele. Vajalik on esituse mõiste fundamentaalne määratlus; nii Peirce'i kui Uexkülli märgimõisted eeldavad liialdatult keerulist semiootilist toimijat. Lihtsaimad esitavad süsteemid ei evi objekte ega omailmu. Minimaalne esitus ja normatiivsuse allikas (mis on vajalik esituse tõlgendamiseks) võivad põhineda M. Bickhard'i interaktivismil. Esmane normatiivsus ehk loomulik huvi põhineb funktsiooni 'kasutus-mõistel': see, mis aitab kaasa tasakaalukauge süsteemi püsimisele, on selle süsteemi jaoks funktsionaalne; iga ennastsäilitava tasakaalukauge süsteemi minimaalne loomulik huvi on täita seda funktsiooni, see on ta eksistentsiaalseks eelduseks. Minimaalne interaktiivne esitus ilmub, kui sellised süsteemid saavad sobivalt umber lülituda kahe või enama enesesäilitamise viisi vahel. Niisuguste esituste tasandil võib areneda võime ära tunda vigu, kuigi süsteemil pole esitusobjekte. Nähtumuslikud objektid ilmuvad keerukamates süsteemides. Kui süsteem loob rea järjest täiendatavaid 'olukorra kujundeid' ja suudab määrata ajalisi invariante selles täiendusprotsessis, siis moodustavad need invariandid objekte süsteemi enda jaoks. Esitaval süsteemil kujuneb seejuures omailm ja võime kogeda triaadseid märke. Suhe esituse ja ta objekti vahel on sel tasemel kas ikooniline või indeksiline. Nii nagu ka Peirce'i semeiootikas, ilmuvad sümbol-märgid kui enamarenenud, kuna sümbolmärgid vajavad keerukamaid süsteeme. 